\title{
Copper-Transporting ATPase 1
}

National Cancer Institute

\section{Source}

National Cancer Institute. Copper-Transporting ATPase 1. NCI Thesaurus. Code C74975.

Copper-transporting ATPase 1 (1500 aa, $163 \mathrm{kDa}$ ) is encoded by the human ATP7A gene. This protein is involved in copper ion homeostasis. 